\title{
PERANCANGAN SISTEM INFORMASI PENGELOLAAN ASET IT BERBASIS WEB PADA PT MANDIRI AXA GENERAL INSURANCE
}

\author{
Nandang Mulyana ${ }^{1}$, Agus Sulistyanto ${ }^{2}$, Verdi Yasin ${ }^{3}$ \\ ${ }^{1}$ Program Studi Sistem Informasi, Departemen Teknik Informatika 2,3 \\ STMIK Jayakarta ${ }^{1,2,3}$ \\ *Corresponte Email: Nandangmulyana8@gmail.com, \\ Author Email: Agus.sulistyanto@gmail.com, verdiyasin29@gmail.com
}

Received: 09-07-2021, Revised: 16-07-2021, Accepted: 18-07-2021

\begin{abstract}
Abstrak
PT Mandiri Axa General Insurance merupakan perusahaan asuransi jiwa patungan antara PT Bank Mandiri (Persero) Tbk dan National Mutual International Pty. Limited (AXA). Telah hadir selama lebih dari 15 tahun di Indonesia untuk memberdayakan masyarakat dalam memiliki kualitas kehidupan yang lebih baik. Saat ini PT Mandiri AXA General Insurance masih menggunakan cara mengolah data persediaan aset IT berupa laptop dan handphone masih menggunakan excel. Setiap data aset IT yang telah diberikan ke karyawan masih dicatat menggunakan excel, sehingga membutuhkan ketelitian yang lebih, untuk menghindari kesalahan dalam penginputan pengiriman aset IT ke karyawan, serta membutuhkan banyak file untuk menghindari corrupt nya file excel. Admin IT juga kesulitan dalam membuat laporan kepada atasan terkait aset IT karena harus mengolah data excel. Tujuan penelitian ini adalah membuat sistem informasi persedian aset IT dengan menggunakan metode SDLC Waterfall dan menggunakan Unified Modeling Language (UML) untuk pemodelan terstruktur serta menggunakan bahasa pemrograman Prepocessor Hypertext Language (PHP) Framework Codeignaiter, Bootstrap dan menggunakan MySQL sebagai database. Dari penelitian dapat dihasilkan sebuah sistem informasi persedian aset IT yang dapat mempermudah Admin IT untuk pengelolaan persedian aset IT pada PT Mandiri AXA General Insurance.
\end{abstract}

Kata kunci: Sistem Informasi, Persedian, PHP, MySQL, Framework,

\section{Abstract}

PT Mandiri Axa General Insurance is a joint life insurance company between PT Bank Mandiri (Persero) Tbk and National Mutual International Pty. Limited (AXA). Has been present for more than 15 years in Indonesia to empower people to have a better quality of life. Currently PT Mandiri AXA General Insurance is still using the method of processing IT asset inventory data in the form of laptops and cellphones still using excel. Every IT asset data that has been given to employees is still recorded using excel, so it requires more accuracy, to avoid errors in inputting IT asset deliveries to employees, and requires a lot of files to avoid corrupt excel files. IT admins also have difficulty in making reports to superiors regarding IT assets because they have to process excel data. The purpose of this study was to create an IT asset inventory information system using the SDLC Waterfall method and using the Unified Modeling Language (UML) for structured modeling and using the Preprocessor Hypertext Language (PHP) Framework Codeignaiter, Bootstrap programming language and using MYSQL as the database. From the research, an IT asset inventory information system can be produced that can facilitate IT Admin for managing IT asset inventory at PT Mandiri AXA General Insurance.

Keywords: Sistem Informasi, Persedian, PHP, MySQL, Framework 


\section{Pendahuluan}

DOI: https://doi.org/10.52362/jmijayakarta.v1i3.498

PT Mandiri AXA General Insurance (MAGI) mulai beroperasi sebagai perusahaan patungan antara dua perusahaan besar, yakni PT Bank Mandiri (Persero) Tbk dan AXA, salah satu perusahaan asuransi terbesar di dunia pada tanggal 25 Oktober 2011.

Dengan dukungan dari jaringan bisnis Bank Mandiri yang luas dan keahlian global AXA, MAGI senantiasa berinovasi dalam menyediakan produk dan jasa asuransi umum bagi para nasabahnya di Indonesia. Melalui 10 kantor pemasaran di 8 kota besar dan 348 bengkel rekanan di 93 kota, MAGI terus berupaya memberikan layanan terbaik kepada seluruh nasabahnya.

Saat ini PT Mandiri AXA General Insurance masih menggunakan cara mengolah data persediaan aset IT berupa laptop dan handphone masih menggunakan excel. Setiap data aset IT yang telah diberikan ke karyawan masih dicatat menggunakan excel, sehingga membutuhkan ketelitian yang lebih, untuk menghindari kesalahan dalam penginputan pengiriman aset IT ke karyawan, serta membutuhkan banyak file untuk menghindari corrupt nya file excel. Admin IT juga kesulitan dalam membuat laporan kepada atasan terkait aset IT karena harus mengolah data excel.

Dalam melakukan aktifitas pencatatan pengelolaan aset IT pada PT Mandiri AXA General insurance memerlukan ketelitian pencatatan aset IT untuk ke akuratan data demi kelancaran proses pengelolaan data. Oleh karena itu, perlu suatu sistem yang dapat membantu PT Mandiri AXA General Insurance secara efektif. Karena permasalahan tersebut maka perlu suatu sistem informasi persediaan aset IT pada PT Mandiri AXA General Insurance.

Dengan adanya permasalahan tersebut, dapat dipastikan bahwa kebutuhan akan keberadaan sistem informasi sangatlah membantu bagi manajemen dalam memonitoring aset IT.

\section{Literatur}

2.1 Perancangan

Menurut Abdul Kadir, perancangan adalah proses penerapan berbagai teknik dan prinsip dengan tujuan untuk mentransformasikan hasil analisa kedalam bentuk yang memudahkan mengimplementasikan. Dari pengertiandi atas dapat disimpulkan perancangan adalah suatukegiatan yang berhubungan berdasarkan evaluasi yang telah dilakukan pada kegiatan analisis [1]

2.2 Aplikasi

Menurut Henky W Permana, istilah aplikasi sendiri diambil dari bahasa Inggris "application" yang dapat diartikan sebagai penerapan atau penggunaan. Secara harfiah, aplikasi merupakan suatu penerapan perangkat lunak atau software yang dikembangkan untuk tujuan melakukan tugas-tugas tertentu [2]

2.3 Website

Menurut Bekti, website merupakan sekumpulan halaman-halaman yang digunakan untuk menampilkan informasi teks, gambar, video, animasi, suara, dan atau gabungan dari semuanya, baik yang bersifat statis maupun dinamis yang membentuk satu rangkaian bangunan yang saling terkait,yang masing-masing dihubungkan dengan jaringan-jaringan halaman[3]

\section{Metode}

3.1 Metode pengumpulan data

Dalam melakukan penelitian cara mengumpulkan data dilakukan dengan metode antara lain sebagai berikut

a. Metode Observasi

Penulis terjun langsung untuk melihat dan mengamati proses pencatatan aset IT, pengolahan data persediaan aset IT dan mencatat permasalahan yang terjadi pada PT Mandiri AXA General Insurance (MAGI).

b. Metode Wawancara 
DOI: https://doi.org/10.52362/jmijayakarta.v1i3.498

Penulis mempelajari dan menganalisa aktifitas yang berada pada PT Mandiri AXA General Insurance (MAGI) serta mendapatkan data langsung dari sumbernya dengan tanya jawab dan wawancara. Diharapkan informasi yang diperoleh benar-benar dapat di pertanggung jawabkan atas pertanyaan yang diajukan.

c. Studi Pustaka

Penulis mengumpulkan dan mempelajari buku - buku yang berkaitan dengan aplikasi yang akan dibuat.

\subsection{Metode Analisis}

Sistem yang sedang berjalan pada PT Mandiri AXA General Insurance (MAGI), terdiri dari beberapa proses, sebagai berikut:

a. Pencatatan Data aset Laptop dan Handphone

b. Pencatatan Data serah terima aset IT ke karyawan

c. Pencatatan Data dikembalikan aset IT dari karyawan

d. Pengolahan laporan aset IT

3.3 Metode Pengembangan

Metode yang dilakukan dalam penelitian ini adalah merancang dan membuat program sistem informasi pengelolaan aset IT PT Mandiri AXA General Insurance (MAGI) dengan langkah langkah antara lain :
a. Mempersiapkan alat dan bahan yang diperlukakan (requirements analysis)
b. Membuat rancangan program
c. Membuat program atau implementasi
d. Menguji program
e. Merevisi program apabila di perlukan

\subsection{Metode Perancangan}

Pada sistem yang akan diusulkan terdapat 1 pengguna sistem, Admin IT yang memiliki semua akses menu pada sistem ini antara lain:

a. Menu Master karyawan yaitu untuk melihat data karyawan, menambahkan, edit, dan hapus data karyawan.

b. Menu Master setup yaitu untuk melihat data master setup, menambahkan, edit, dan hapus data master setup.

c. Menu aset IT yaitu untuk membuat data barang atau aset IT, menghapus, edit data aset aset IT, serah terima aset IT ke karyawan dan mengembalikan aset IT ke gudang dari karyawan.

d. Menu Laporan yaitu untuk mendownload laporan aset IT yang akan diberikan kepada atasan

\subsection{Metode Pengujian}

Dalam metode pengujian ini, peneliti akan menggunakan pengujian terhadap program yang dibuat menggunakan blackbox testing yang fokus terhadap proses masukan dan keluaran program yang meliputi :

a. Pengujian terhadap login dan logout.

b. Pengujian terhadap tambah, edit, dan delete data master karyawan

c. Pengujian terhadap tambah, edit, hapus data aset IT, serah terima aset IT, mengembalikan aset IT.

d. Pengujian terhadap download laporan aset IT. 
DOI: https://doi.org/10.52362/jmijayakarta.v1i3.498

\section{$4 \quad$ Hasil dan Pembahasan}

4.1 Lokasi Penelitian

Adapun lokasi tempat penelitian ini dilakukan pada PT Mandiri AXA General Insurance (MAGI) yang merupakan perusahan bergerak dibidang asuransi, yang berdiri sejak 2011, yang terletak di Jl. Prof. DR. Satrio No.Kav 18, RT.14/RW.4, Kuningan, Karet Kuningan, Kecamatan Setiabudi, Kota Jakarta Selatan, Daerah Khusus Ibukota Jakarta 12940. Berikut adalah gambar maps tempat penelitian PT Mandiri AXA General Insurance (MAGI).

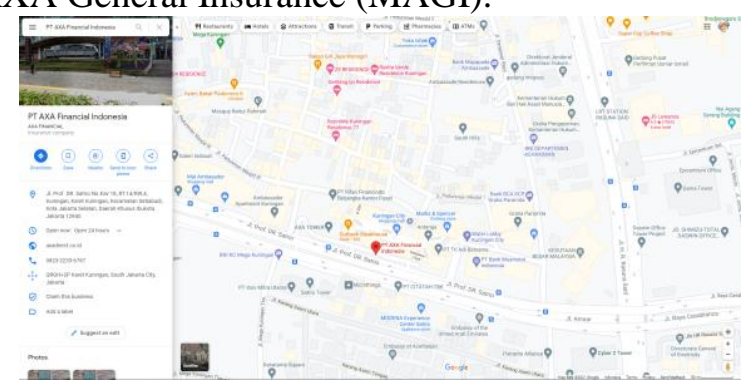

Gambar 4.1 Tempat PT Mandiri AXA General Insurance (MAGI)

4.2 Rancangan Use Case Diagram aplikasi ase

Berikut ini gambar Use Case Diagram pada sistem berjalan.

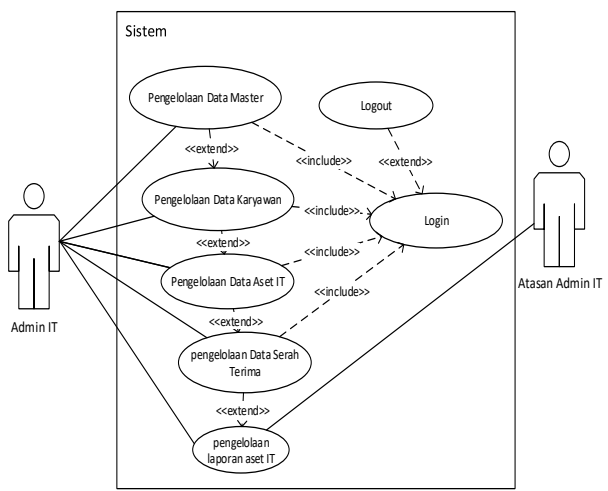

Gambar 4.2 Use Case Diagram Sistem berjalan

Dalam use case diagram sistem berjalan terdapat actor yaitu admin IT, dan Atasan admin IT, admin IT bertugas mencatat nama karyawan, nama aset, serta mencatat serah terima aset ke karyawan, serta mencatat pengembalian aset, dari karyawan ke gudang.

\subsection{Rancangan Activity Diagram}

Adapun prosedur sistem yang sedang berjalan pada PT Mandiri AXA General Insurance akan dijelaskan pada Activity berikut ini :

a. Activity diagram serah terima aset IT 
DOI: https://doi.org/10.52362/jmijayakarta.v1i3.498

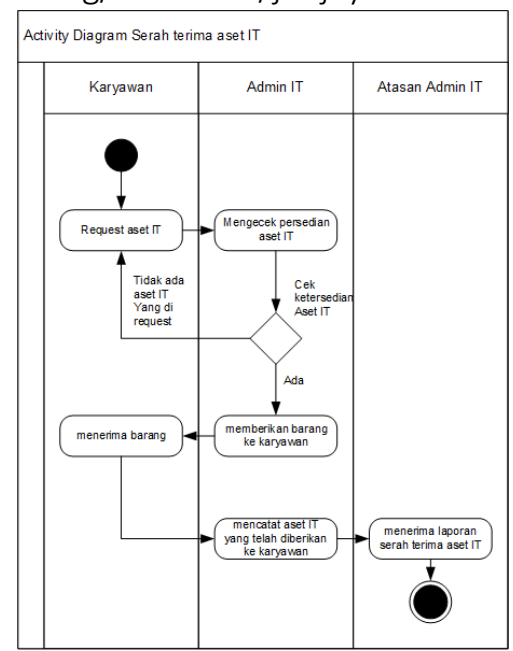

Gambar 4.3 Use Case Diagram Serah terima aset IT

b. Activity diagram pengembalian aset IT

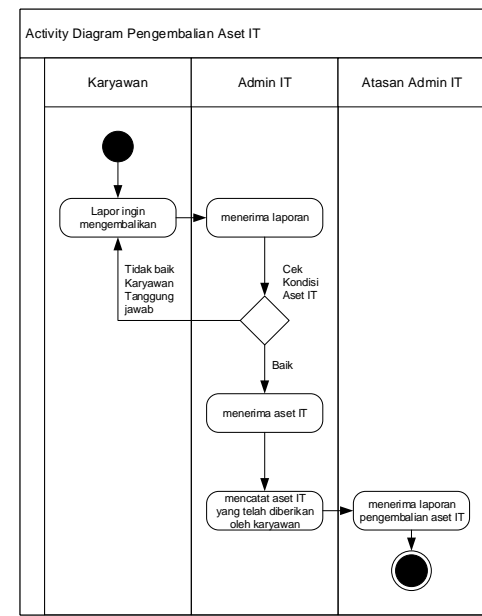

Gambar 4.4 use case diagram pengembalian aset IT

4.4 Rancangan Sequence Diagram

a. Rancangan sequence diagram login

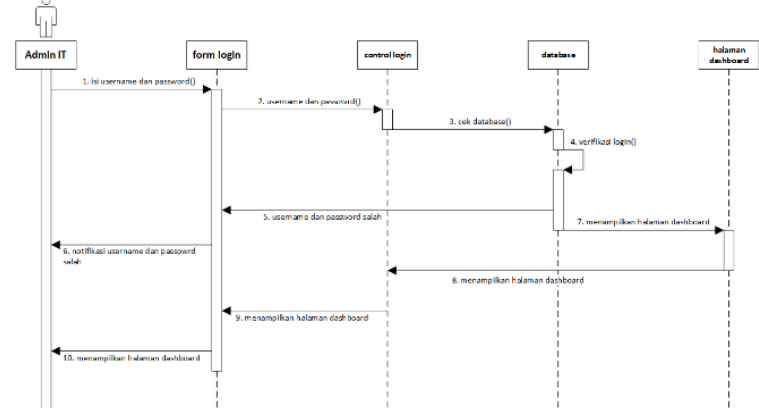

Gambar 4.5 rancangan sequence diagram login 
DOI: https://doi.org/10.52362/jmijayakarta.v1i3.498

Pada gambar 4.5 di atas menunjukan tentang sequence diagram login yang dilakukan oleh admin IT, dimana admin IT memasukan username dan password, untuk mengakses sistem informasi aset IT.

b. Rancangan sequence diagram menu master setup

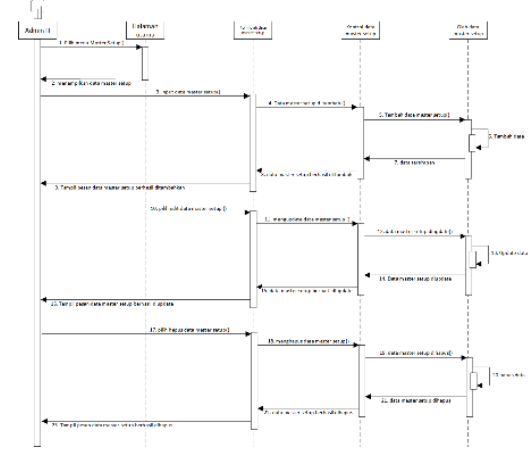

Gambar 4.6 rancangan sequence diagram menu master setup

Pada gambar 4.6 di atas menunjukan tentang sequence diagram menu master setup, dimana admin IT dapat melihat data data master setup pada sistem informasi aset IT, kemudian jika admin IT menginput data master setup di form olah data master setup lalu ke control data master setup dan data langsung tersimpan ke database olah data master setup. Kemudian jika admin IT ingin mengupdate data master setup, admin IT mengedit data master setup, melewati form olah data master setup dan data langsung tersimpan ke database olah data master setup. Dan terakhir jika admin IT melakukan menghapus data master setup pada table data master setup dan data langsung terhapus.

c. Rancangan sequence diagram menu master karyawan

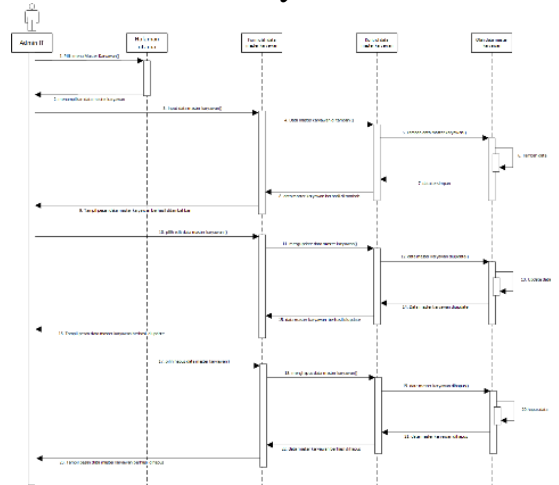

Gambar 4.7 rancangan sequence diagram menu master karyawan

Pada gambar 4.7 di atas menunjukan tentang sequence diagram menu master karyawan, dimana admin IT dapat melihat data data master karyawan pada sistem informasi aset IT, kemudian jika admin IT menginput data master karyawan di form olah data master karyawan lalu ke control data master karyawan dan data langsung tersimpan ke database olah data master karyawan. Kemudian jika admin ingin mengupdate data master karyawan, admin IT mengedit data master karyawan, melewati form olah data master karyawan dan data langsung tersimpan ke database olah data master karyawan. Dan terakhir jika admin IT melakukan menghapus data master karyawan pada table data master karyawan dan data langsung terhapus.

d. Rancangan sequence diagram menu aset IT 
DOI: https://doi.org/10.52362/jmijayakarta.v1i3.498

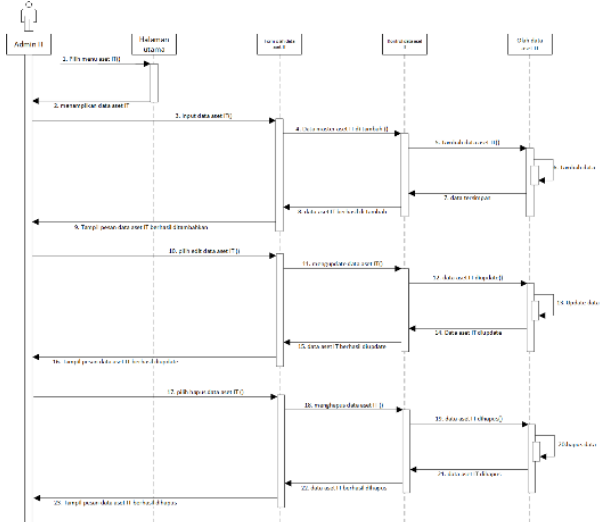

Gambar 4.8 rancangan sequence diagram menu aset IT

Pada gambar 4.8 di atas menunjukan tentang sequence diagram menu aset IT, dimana admin IT dapat melihat data data aset IT pada sistem informasi aset IT, kemudian jika admin IT menginput data aset IT di form olah data aset IT lalu ke control data aset IT dan data langsung tersimpan ke database olah data aset IT. Kemudian jika admin ingin mengupdate data aset IT, admin IT mengedit data aset IT, melewati form olah data aset IT dan data langsung tersimpan ke database olah data aset IT. Dan terakhir jika admin IT melakukan menghapus data aset IT pada table data aset IT dan data langsung terhapus.

e. Rancangan sequence diagram serah terima aset IT

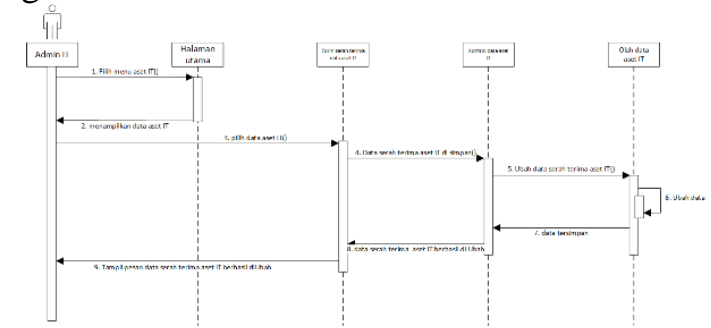

Gambar 4.9 rancangan sequence diagram serah terima aset IT

Pada gambar 4.9 di atas menunjukan tentang sequence diagram serah terima aset IT, dimana admin IT dapat melihat data data aset IT pada sistem informasi aset IT, kemudian admin IT memilih data aset IT yang akan diserahkan ke karywan di form olah data aset IT lalu ke control data aset IT dan data langsung tersimpan ke database olah data aset IT.

f. Rancangan sequence diagram mengembalikan aset IT 
DOI: https://doi.org/10.52362/jmijayakarta.v1i3.498

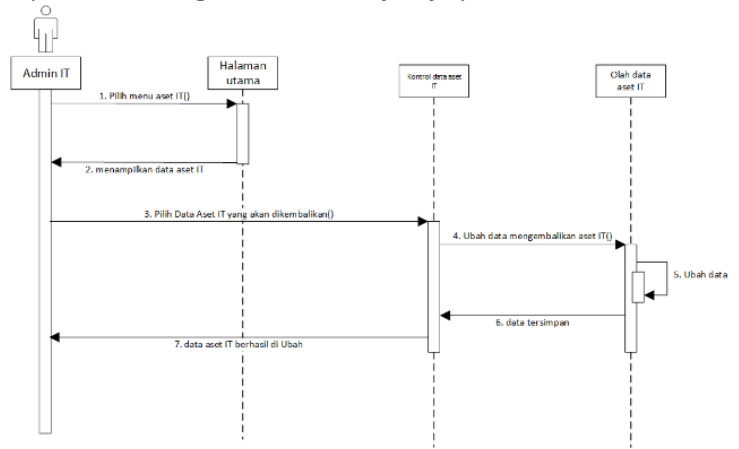

Gambar 4.10 rancangan sequence diagram mengembalian aset IT

Pada gambar 4.10 di atas menunjukan tentang sequence diagram mengembalikan aset IT, dimana admin IT dapat melihat data data aset IT pada sistem informasi aset IT, kemudian admin IT memilih data aset IT yang akan mengembalikan aset IT lalu ke control data aset IT dan data langsung tersimpan ke database olah data aset IT.

g. Rancangan sequence diagram Laporan aset IT

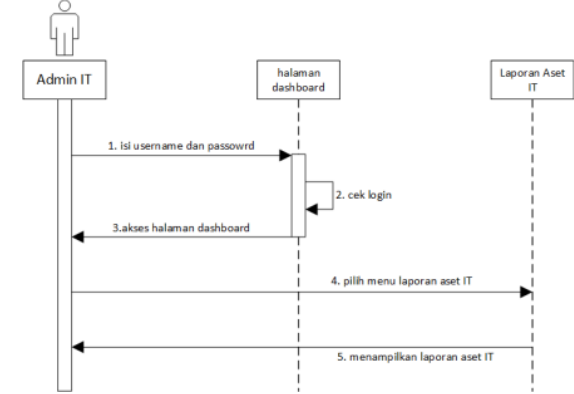

Gambar 4.11 rancangan sequence diagram laporan aset IT

Pada Gambar 4.11 di atas menunjukan tentang sequence diagram laporan aset IT, dimana admin IT dapat melihat laporan aset IT

4.5 Rancangan class diagram

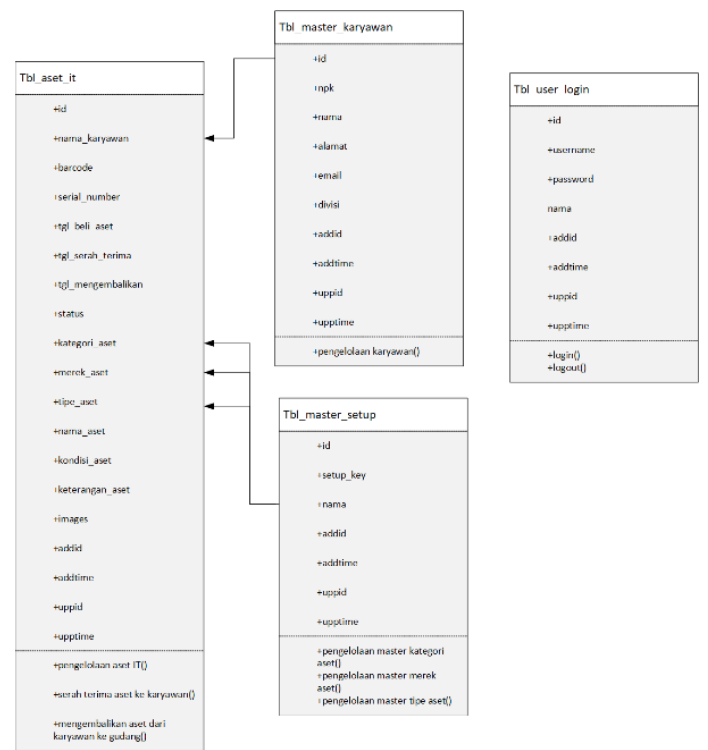

Gambar 4.12 rancangan class diagram 
DOI: https://doi.org/10.52362/jmijayakarta.v1i3.498

4.6 Rancangan Tampilan

a. Rancangan Halaman Login

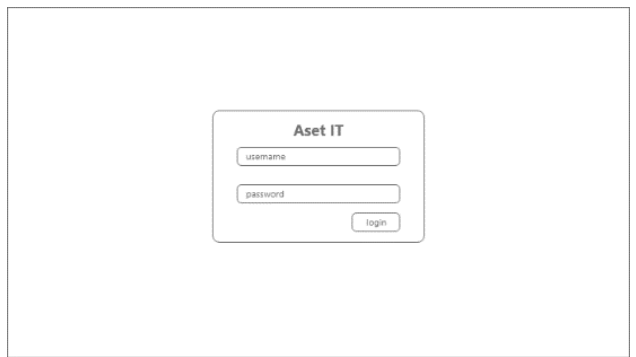

Gambar 4.13 halaman login

b. Rancangan Halaman dashboard sesudah login

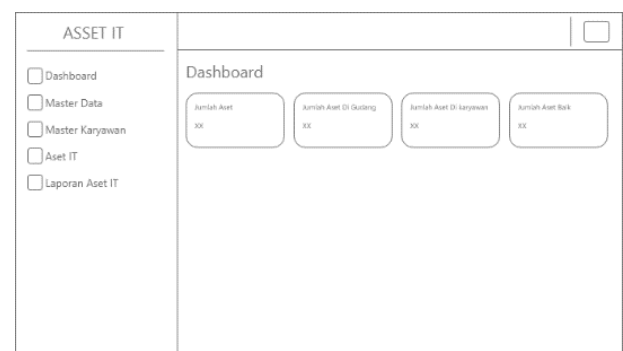

Gambar 4.14 halaman dashboard

c. Rancangan Halaman menu master setup

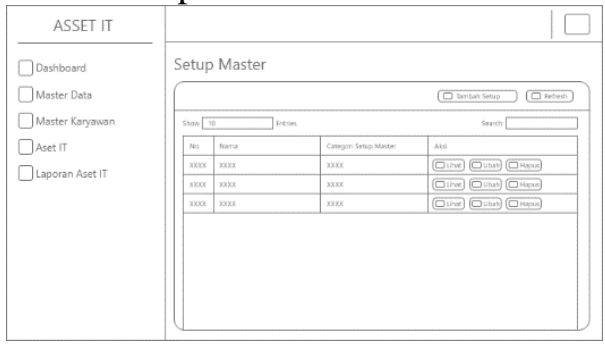

Gambar 4.15 halaman master setup

d.Rancangan Halaman menu tambah master setup

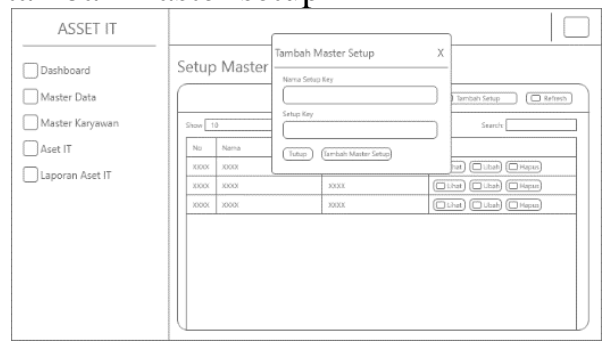

Gambar 4.16 halaman tambah master setup

e. Rancangan Halaman menu master karyawan 
DOI: https://doi.org/10.52362/jmijayakarta.v1i3.498

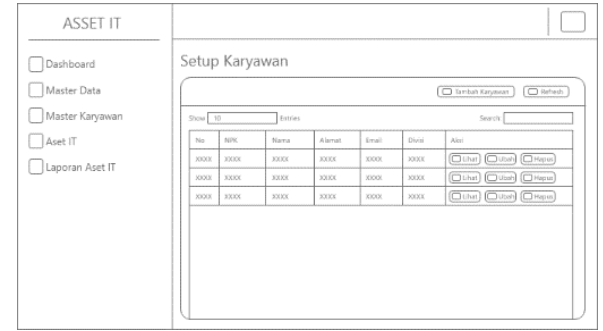

Gambar 4.17 halaman master karyawan

f. Rancangan Halaman menu tambah master karyawan

Gambar 4.18 halaman tambah master karyawan

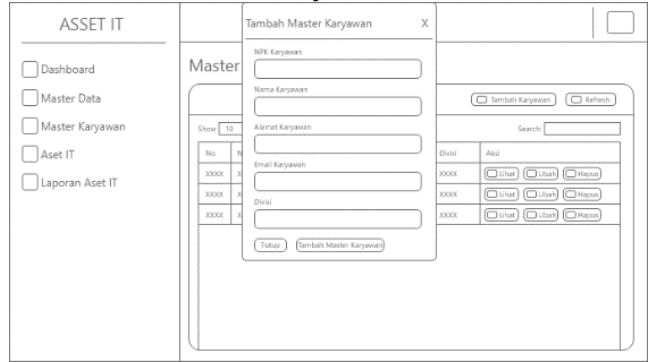

g. Rancangan Halaman menu aset IT

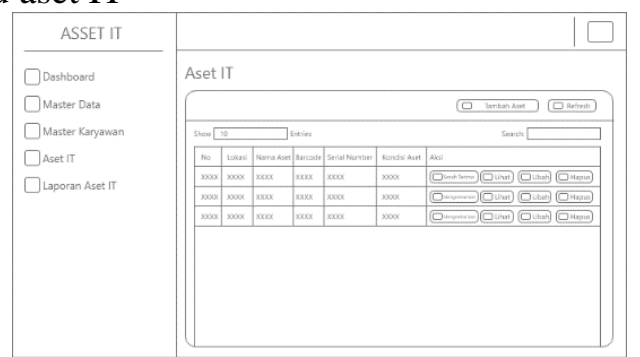

Gambar 4.19 halaman menu aset IT

h.Rancangan Halaman menu tambah aset IT

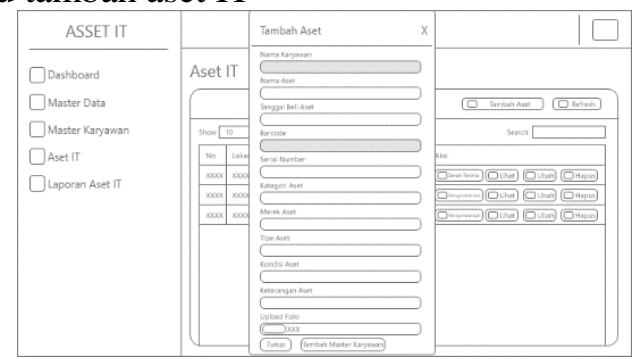

Gambar 4.20 halaman menu tambah aset IT

i. Rancangan Halaman menu serah terima aset IT

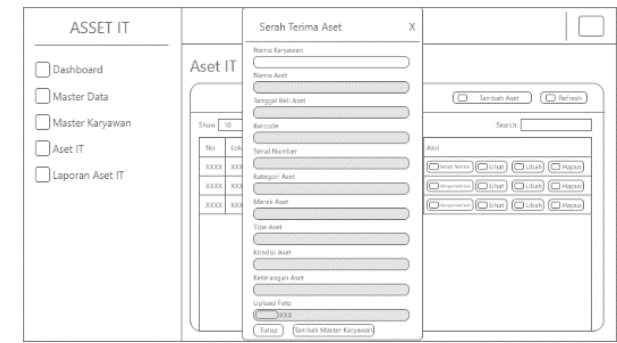

This work is licensed under a Creative Commons Attribution 4.0 International License. http://journal.stmikjayakarta.ac.id/index.php/JMIJayakarta 
DOI: https://doi.org/10.52362/jmijayakarta.v1i3.498

Gambar 4.21 halaman menu serah terima aset IT

j. Rancangan Halaman menu mengembalikan aset IT dari karyawan ke gudang

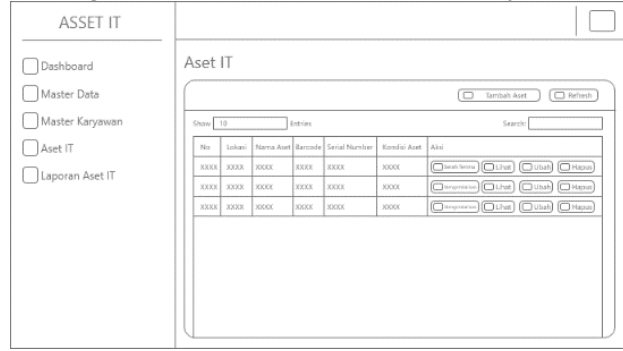

Gambar 4.22 halaman menu mengembalikan aset IT dari karyawan ke gudang

k. Rancangan Halaman menu laporan aset IT

Gambar 4.23 halaman menu laporan aset IT

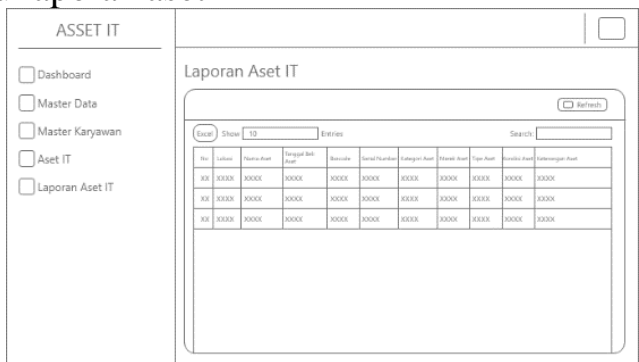

4.7 Implementasi

a. Tampilan Login

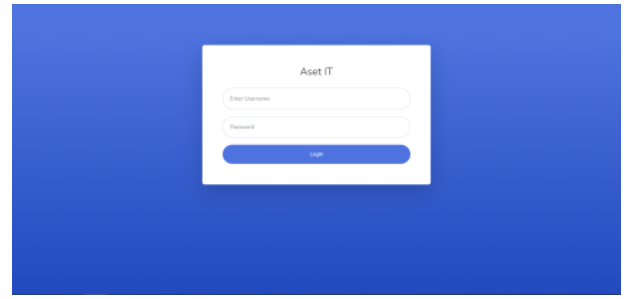

Gambar 4.24 Tampilan Login

b.Tampilan halaman dashboard
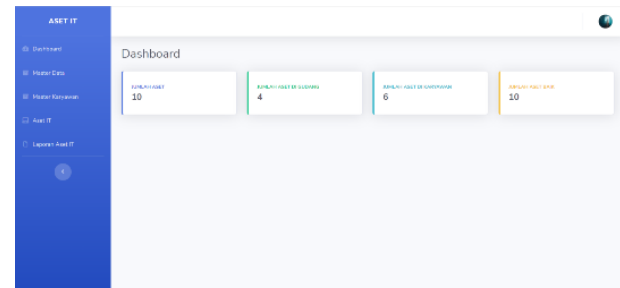

Gambar 4.25 Tampilan halaman dashboard 
DOI: https://doi.org/10.52362/jmijayakarta.v1i3.498

c. Tampilan halaman menu master setup

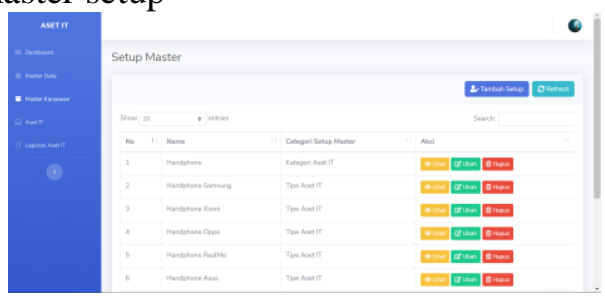

Gambar 4.26 Tampilan halaman menu master setup

d.Tampilan halaman menu tambah master setup

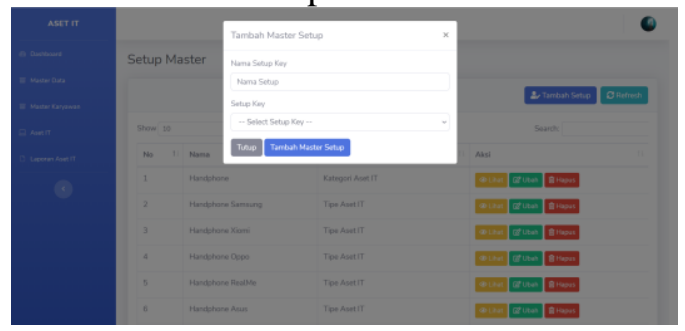

Gambar 4.27 Tampilan halaman menu tambah master setup

e. Tampilan halaman menu master karyawan

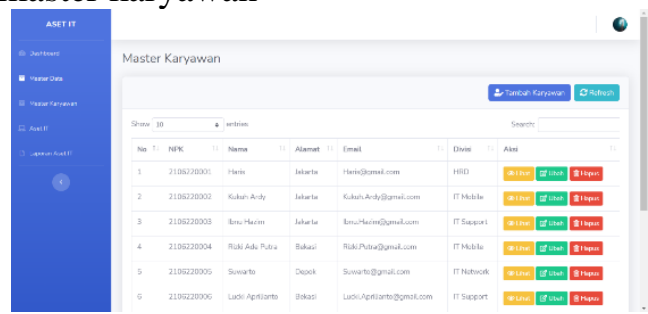

Gambar 4.27 Tampilan halaman menu master karyawan

f. Tampilan halaman menu tambah master karyawan

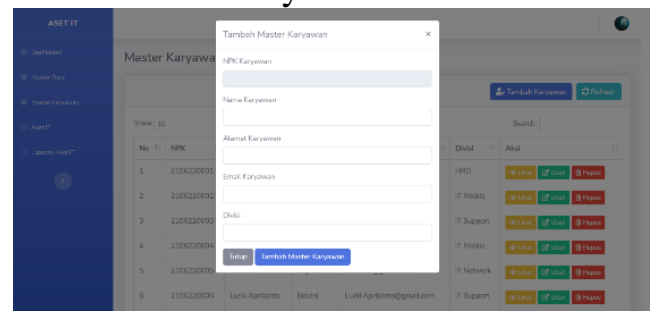

Gambar 4.28 Tampilan halaman menu master karyawan

g. Tampilan halaman menu aset IT

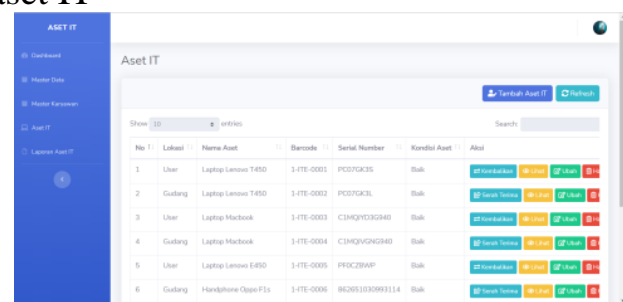

Gambar 4.29 Tampilan halaman menu aset IT

\section{(a)}

This work is licensed under a Creative Commons Attribution 4.0 International License. http://journal.stmikjayakarta.ac.id/index.php/JMIJayakarta 
DOI: https://doi.org/10.52362/jmijayakarta.v1i3.498

h.Tampilan halaman menu tambah aset IT

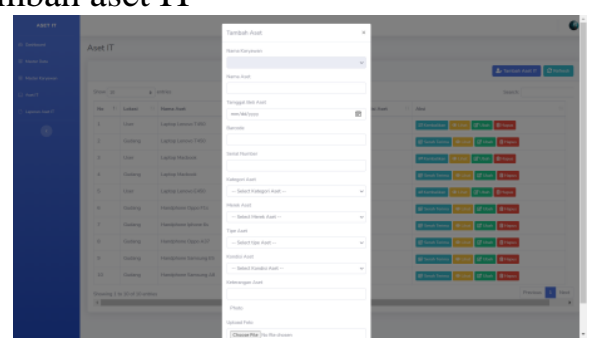

Gambar 4.30 Tampilan halaman menu tambah aset IT

i. Tampilan halaman menu serah terima aset IT

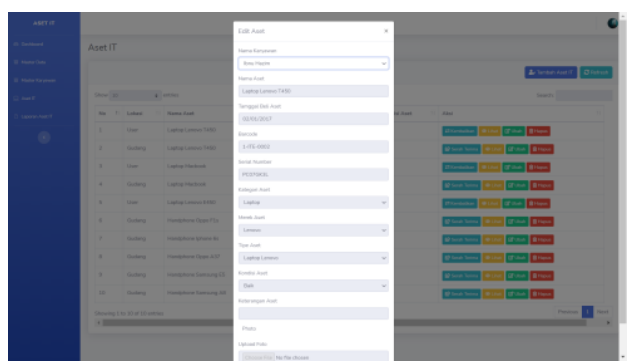

Gambar 4.31 Tampilan halaman menu serah terima aset IT

j. Tampilan halaman menu mengembalikan aset IT

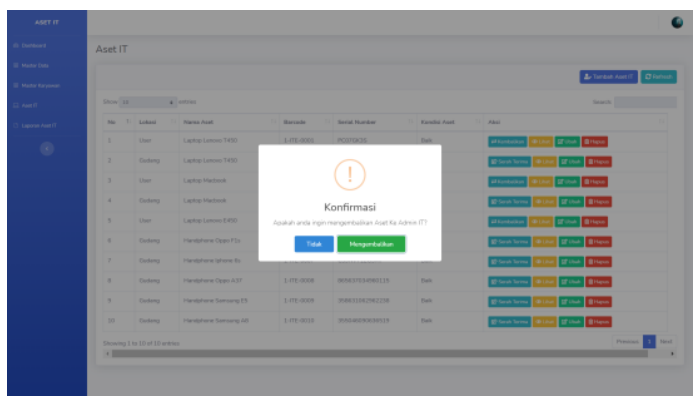

Gambar 4.32 Tampilan halaman menu mengembalikan aset IT

k. Tampilan halaman menu laporan aset IT

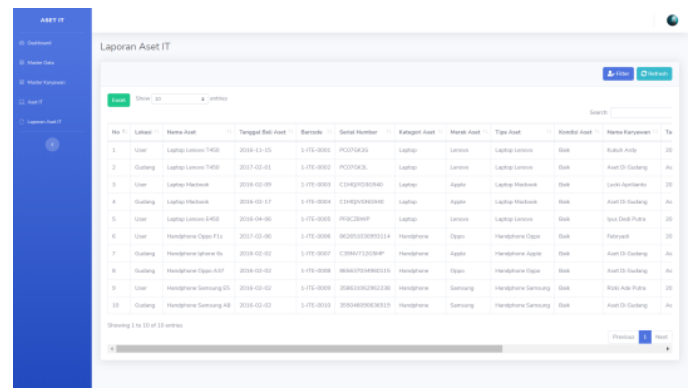

Gambar 4.33 Tampilan halaman menu laporan aset IT

1. Tampilan download excel dari laporan aset IT

\section{(c)}

This work is licensed under a Creative Commons Attribution 4.0 International License. http://journal.stmikjayakarta.ac.id/index.php/JMIJayakarta 


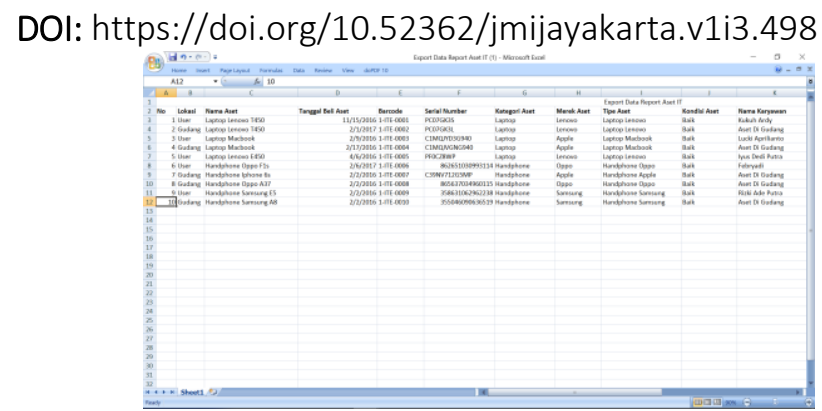

Gambar 4.34 Tampilan download excel dari laporan aset IT

\section{Kesimpulan}

5.1 Simpulan

Dari hasil penelitian yang didapat, maka penulis menarik kesimpulan bahwa:

a. Telah dihasilkan sebuah sistem informasi yang dapat memantau aktivitas aset IT

b. Telah dihasilkan sebuah sistem yang dapat memudahkan admin IT dalam mengelola aset

c. Telah dihasilkan sebuah sistem yang mampu memberikan kemudahan kepada admin IT dalam ngelola laporan aset .

\subsection{Saran}

Berdasarkan hasil dari penelitian di lapangan maka penulis bermaksud ingin memberikan saran yang ditujukanuntuk penelitianselanjutnya sebagai berikut:

a. Sebaiknya sistem aplikasi aset IT berbasis web diberikan penambahan fitur email agar karyawan yang mememgang aset mendapatkan notifikasi penyerahan aset.

b.Sebaiknya sistem aplikasi aset disediakan domain privete pada perusahan

\section{Referensi}

[1] Abdul Kadir. (2003).Pengenalan Sistem Informasi, Andi, Yogyakarta.

[2] Henky Permana.(2019).Pengertian Aplikasi: Arti, Fungsi, Klasifikasi, dan Contoh Aplikasi,https://www.maxmanroe.com/vid/teknologi/pengertian-aplikasi.html, Diakses12 Desember. 2019

[3] Bekti, B. H. (2015). Mahir Membuat Website Dengan Adobe. Dreamweaver CS6, CSS dan JQuery. Yogyakarta: ANDI

[4] Verdi Yasin (2012) 'Rekayasa Perangkat Lunak Berorientasi Objek”, Penerbit: Mitra Wacana Media, Jakarta-Indonesia.

[5] Anis Rohmadi, Verdi Yasin (2020) "Desain Dan Penerapan Website Tata Kelola Percetakan Pada CV Apicdesign Kreasindo Jakarta Dengan Metode Prototyping", Journal of

Information System, Informatics and Computing. E-ISSN: 2597-3673 (Online), P-ISSN: 2579-5201 (Print) Vol. 4 No.1, June 22, 2020. Pp.70-85 http://journal.stmikjayakarta.ac.id/index.php/jisicom/article/view/210

[6] Septian Cahyadi, Verdi Yasin, Mohammad Narji, Anton Zulkarnain Sianipar (2020) "Perancangan Sistem Informasi Pengiriman Dan Penerimaan Soal Ujian Berbasis Web ( Studi Kasus: Fakultas Komputer Universitas Bung Karno)", Journal of Information System, Informatics and Computing. E-ISSN: 2597-3673 (Online), P-ISSN: 2579-5201 (Print) Vol. 4 No.1, June 22, 2020. Pp.1-16 http://journal.stmikjayakarta.ac.id/index.php/jisicom/article/view/199

[7] Ifan Junaedi, Ndaru Nuswantari, Verdi Yasin (2019) "Perancangan Dan Implementasi Algoritma C4.5 Untuk Data Mining Analisis Tingkat Risiko Kematian Neonatum Pada Bayi”, Journal of Information System, Informatics and Computing. E-ISSN: 2597-3673 (Online), P- 
DOI: https://doi.org/10.52362/jmijayakarta.v1i3.498

ISSN: 2579-5201 (Print) Vol. 3 No.1, February 13, 2019. Pp.29-44.

http://journal.stmikjayakarta.ac.id/index.php/jisicom/article/view/203

[8] Verdi Yasin, Anindra Ramdhan Nugraha, Muhammad Zarlis, Ifan Junaedi (2018) "Smart System Of Fast Internet Access Development Using Backbone Network Method", Journal of Information System, Informatics and Computing. E-ISSN: 2597-3673 (Online), $P$ ISSN: 2579-5201 (Print) Vol. 2 No. 2, December 31, 2018. Pp.26-34. http://journal.stmikjayakarta.ac.id/index.php/jisicom/article/view/198

[9] Ito Riris Immasari, Verdi Yasin (2019) "Penggunaan Metode Analytic Hierarchy Process Untuk Menganalisis Faktor-Faktor Yang Mempengaruhi Pemilihan Calon Legislatif Di Dprd Ii Kota Tangerang", Journal of Information System, Informatics and Computing. E-ISSN: 2597-3673 (Online), P-ISSN: 2579-5201 (Print) Vol. 3 No. 2, December 10, 2019. Pp.53-58. http://journal.stmikjayakarta.ac.id/index.php/jisicom/article/view/139

[10] Verdi Yasin, Muhammad Zarlis, Tulus, Erna Budhiarti Nababan, Poltak Sihombing (2019)

"Rancangan Miniatur Otomatisasi Bel Listrik Pada Gerbang Pintu Menggunakan Microkontroler Atmega8535", Journal of Information System, Informatics and Computing. E-ISSN: 2597-3673 (Online), P-ISSN: 2579-5201 (Print) Vol. 3 No. 1, February 13, 2019. Pp.13-20 http://journal.stmikjayakarta.ac.id/index.php/jisicom/article/view/68

[11] Anggeri S. Nurjaman, Verdi Yasin (2020) "Konsep Desain Aplikasi Sistem Manajemen Kepegawaian Berbasis Web Pada PT. Bintang Komunikasi Utama ”, Journal of Information System, Informatics and Computing. E-ISSN: 2597-3673 (Online), P-ISSN: 2579-5201 (Print) Vol. 4 No. 2, December 28, 2020. Pp.143-174. http://journal.stmikjayakarta.ac.id/index.php/jisicom/article/view/363

[12] Verdi Yasin, Azhar Ahmad Riza, Rumadi Hartawan (2017) "Pengembangan Aplikasi Pemulihan Layanan Bencana Sistem Informasi Peneriman Negara Bukan Pajak Online Di Lingkungan Kementerian Keuangan Republik Indonesia”, Journal of Information System, Informatics and Computing. E-ISSN: 2597-3673 (Online), P-ISSN: 2579-5201 (Print) Vol. 1 No. 1, September 20, 2017. Pp.33-56.

http://journal.stmikjayakarta.ac.id/index.php/jisicom/article/view/4 